\title{
Approach to Foreign Body Aspiration in an Infant Using a Cryoprobe
}

\author{
Kriyoprob Kullanarak bir Bebekte Yabancı Cisim Aspirasyonuna Yaklaşım
}

Mohammad Ashkan Moslehi

\begin{abstract}
Foreign body (FB) aspiration is a true medical emergency that occurs due to airway obstruction in which immediate removal is crucial. Rigid bronchoscopy is the preferred method for the removal of foreign bodies lodged in the airways, however studies have found that a flexible bronchoscopy can achieve greater success rates. Recently, although there have been reports of a cryoprobe being used for the removal of FBs in adults, in pediatrics, and especially in infancy, there is little experience about its use, in that tracheobronchial FB aspiration is an infrequently encountered event among neonates and in early infancy. This report highlights the efficacy of using a cryoprobe for a flexible bronchoscopy for the management of a retained FB in a young infant.
\end{abstract}

Key words: Foreign body aspiration, Bronchoscopic treatment, Cryotherapy, Infant.

\section{Özet}

Yabancı cisim aspirasyonu, hava yolu obstrüksiyonuna neden olduğu için acil bir tıbbi durumdur ve bu nedenle, bu tür durumlarda yabancı cismin hemen çıkarılması çok önemlidir. Rijit bronkoskopi, yabancı cisimlerin çıkarılmasında ilk tercih edilen yöntemdir, ancak bazı çalışmalar flexible bronkoskopinin de yüksek başarı oranı sağlayabildiğini göstermiştir. Son zamanlarda, erişkinlerde, yabancı cisimlerin çıkarılmasında, kriyoprobun kullanımıyla ilgili bazı bildirimler vardır. Fakat pediatrik grupta, özellikle yeni doğan ve infant dönemde, nadiren karşılaşılan bir durum olduğu için kullanımı konusunda çok az deneyim vardır. Biz de infant dönemde yabancı cisim aspirasyonu olan olgumuzda, flexible bronkoskopi ile kriyoprob kullanmanın da etkinliğini vurgulamak ve bu konudaki deneyimlere katkıda bulunmak için olgumuzu sunmayı amaçladık.

Anahtar Sözcükler: Yabancı cisim aspirasyonu, Bronkoskopik tedavi, Kriyoretapi, Infant.

Pediatric Interventional Pulmonology Department, Shiraz University Şiraz Tıp Bilimleri Üniversitesi, Çocuk Cerrahisi Pulmonoloji of Medical Sciences, Shiraz, Iran Anabilim Dalı Başkanı, Şiraz, İran

Submitted (Başvuru tarihi): 11.09.2019 Accepted (Kabul tarihi): 29.11.2019

Correspondence (iletişim): Mohammad Ashkan Moslehi, Pediatric Interventional Pulmonology Department, Shiraz University of Medical Sciences, Shiraz, Iran

e-mail: ashkanmoslehi@gmail.com 
Foreign body aspiration in childhood is a common and potentially serious problem. A thorough history and a physical examination are of paramount importance in the evaluation of a child with a suspected FB, as this can frequently lead to a diagnosis without the need for further diagnostic workups or imaging. The majority of FB aspirations are observed in children aged 4 years and younger (1). Choking, coughing, stridor, wheezing and vocal changes are the most common indications that a may have aspirated a foreign body. Treatment depends on the time of aspiration, and the location, type and size of the foreign body. A bronchoscopy may be needed to remove the item. There are some clear advantages to use of the RB for the removal of a tracheobronchial FB, however modern endoscopic equipment is available in various sizes and configurations to suit the patient's age and size. Furthermore, both flexible and rigid endoscopic equipment are currently available.

\section{CASE}

A challenging case of 7-month-old female infant was presented with progressively increasing stridor, coughing, cyanotic spells and respiratory distress over the past 2 weeks. The parents provided a history, stating that the problem had started while the patient was playing with her elder sister when she started showing the signs of choking and coughing, and became cyanotic and breathless. AN examination revealed severe respiratory distress, inspiratory stridor, localized wheeze and reduced air entry on the left side. Oxygen saturation was variable, but mostly around $80-85 \%$ in room air. A chest $X$-ray showed a left side whiteout lung with collapse due to a severe obstruction on the left side with a mediastinal shift (Figure 1). This case was rare in that it is unusual for an FB to lodge distally in the left bronchus, especially in such a small infant. An urgent RB was performed in the operation room, but the surgeon was unable to extract the FB as it was lodged distally, out of the range of a rigid bronchoscope, and was embedded within granulation tissue. Moreover, the patient's condition became worse during the rigid bronchoscopy procedure, so the infant was intubated and transferred to the PICU. The surgeon asked our department to manage the patient, and after talking to the parents, they gave us consent to make a further investigation with a fiberoptic bronchoscopy, and if possible, to remove the FB using the Cryoprobe. The patient was transferred to our bronchoscopy suite and underwent our sedation protocol, in which atropine was administered to decrease trachea-bronchial secretions, an intermittent intravenous injection of Propofol for light sedation, and strict dose monitoring to maintaining the patient's spontaneous breathing. As a primary investigation, first, a $2.8 \mathrm{~mm}$ fiberoptic bronchoscope was passed through the ETT. The bronchoscopy confirmed the presence of an FB in the left main bronchus with inspissated thick mucosal secretions and some granulation tissue. To maintain the oxygen level, the long nasal prongs were placed in the hypopharynx above the vocal cords. After applying suction, and applying an epinephrine solution, the patient was extubated, as the author had to use a 4.3 bronchoscope with a $2 \mathrm{~mm}$ working channel for the passage of a thin $2 \mathrm{~mm}$ cryoprobe (ERBE Elektromedizin $\mathrm{GmbH}$, Germany). The bronchoscope was placed in the best possible position to access the object. Using the cryoprobe, freezing was applied to the head of the FB for 5 seconds. After creating an ice ball formation, the object was disengaged from the mucosa and was moved proximally into the trachea. In the following stage, through continuous freezing (without releasing the foot pedal), the FB was attached tightly to the tip of the cryoprobe and was fully removed en bloc, along with the flexible bronchoscope. The FB was a nut particle (Figure 2). After cryoextraction, the bronchoscope was again navigated into the involved airway to look for any complications and to remove the secretions. Only thick mucosal secretions that had been trapped behind the obliterated bronchus were noted, and were removed by suction through the working channel.

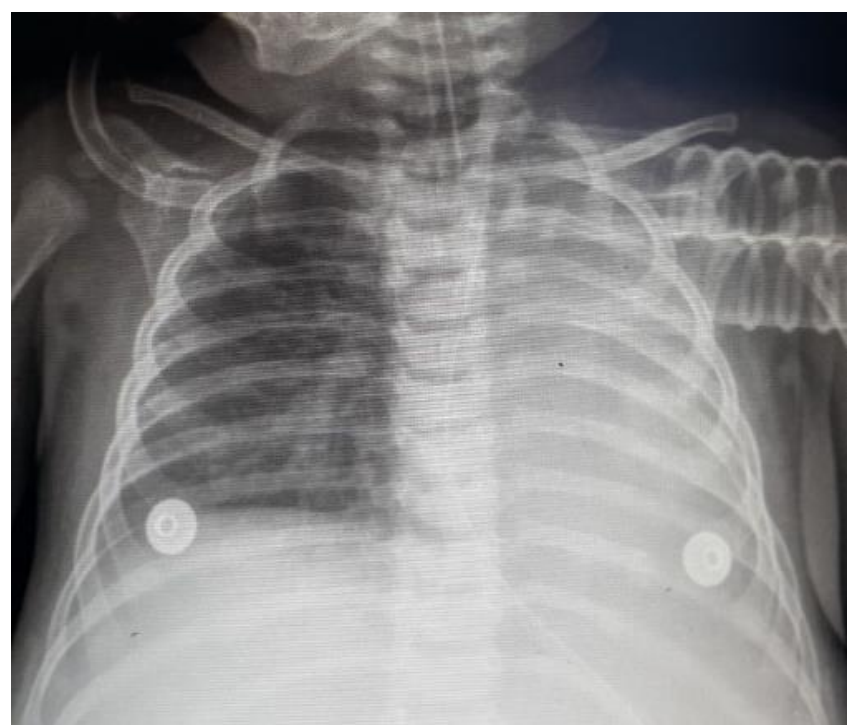

Figure 1: Chest X-ray showing the left side whiteout lung 

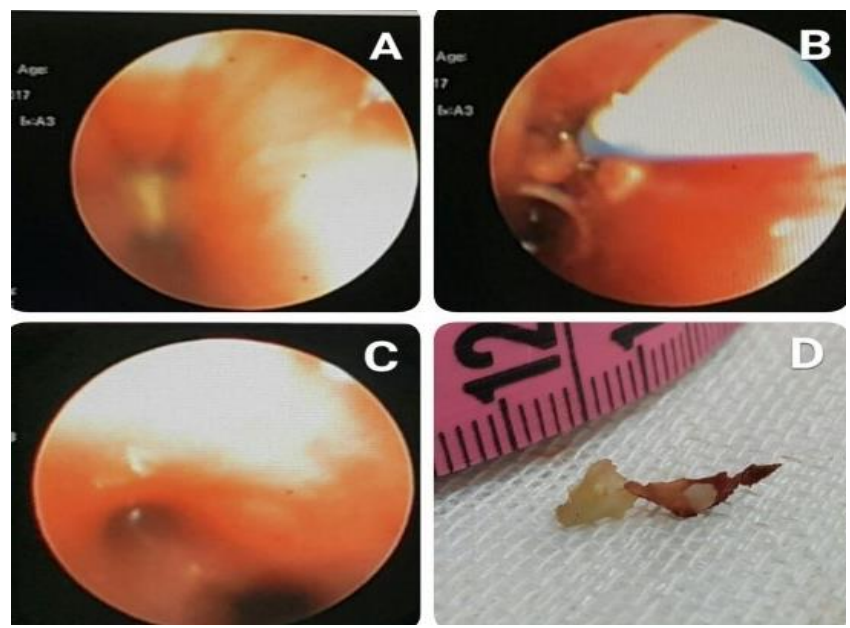

Figure 2: Left main bronchus fully obliterated by the FB embedded in the granulation tissue (A), Using the cryoprobe with repeated freezingthawing cycles pointing at the head of the object (B), Left Lower lobe after the FB removal (C), FB (nut particle) (D)

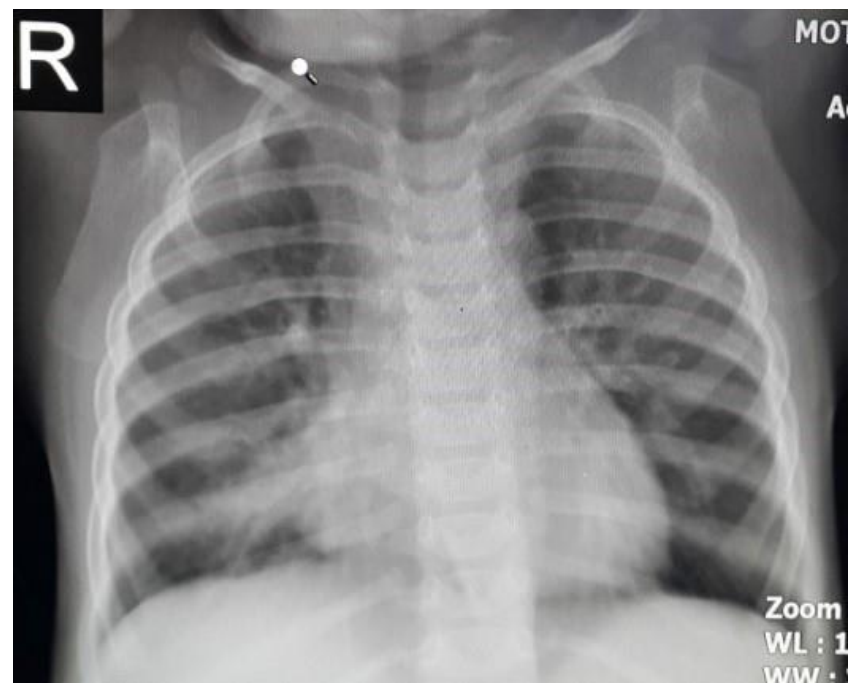

Figure 3: Chest X-ray obtained after the procedure showing a fully expanded left side lung

The slight bleeding that occurred was easily managed through the installation of diluted adrenalin (1:10000). Nebulization (Salbutamol $1.5 \mathrm{mg}$, and adrenalin 1:1000 two $\mathrm{ml}$ diluted in $2 \mathrm{ml}$ normal saline) and steroids (IV Dexamethasone $1.5 \mathrm{mg}$ every 8 hourly) were applied postoperatively. The post-operative period was uneventful. A chest $X$-ray obtained after the procedure showed a fully normal expanded lung on the left side (Figure 3).

\section{DISCUSSION}

Retained FBs, especially in the pediatric age group, can be one of the most challenging problems for interventional bronchoscopists, and may result in such serious complications as pneumonia, atelectasis or bronchiectasis (2). The risk associated with these long-term complications is increased as the time from aspiration to diagnosis increases. Remained FBs can be classified into two groups: primary (due to late diagnosis or Silence FB aspiration syndrome) and secondary (due to unsuccessful bronchoscopy) (1). RB is the optimum treatment approach to the management of FBs in all ages, however the retrieval of FBs through the use of an RB can be hampered by several factors, including the type and diameter of the $F B$, the time elapsed since diagnosis, the place in which the FB is lodged and the extent to which it is embedded by granulation tissue. The age of the child is also very important, as in younger children, the diameter of the airway may be too small to pass an RB and accessories (such as forceps, baskets), which increases the chance of unsuccessful attempts at removal. Recently the use of fiberoptic bronchoscopes for the retrieval of pediatric airway FBs has increased. The smaller size and better navigational properties of flexible bronchoscopes permit the examination of the lower airways with fewer traumas, which is not possible with a rigid bronchoscope (3). There have been many studies reporting on the successful use of various instruments, such as forceps or baskets, for the extraction of foreign bodies in the airway $(4,5)$. Although there have been studies into the cryoextraction of FBs, there have been few case reports and studies examining the safety and efficacy of this method in young infants. In the most recent study conducted in pediatrics, the studied cases were older than 10 months and their weight were more than $10 \mathrm{~kg}$. Zhang et al. concluded that removal of foreign bodies from the airways of children using flexible bronchoscopy $\mathrm{CO} 2$ cryotherapy may be considered a safe, easy and effective method (6). To the best of the author's knowledge, the index case is unique, in that the age and weight of the patient were lower than the cases published in the literature to date. The FB was lodged distally in the left lower lobe bronchus, and more interesting, the extraction with the RB wasn't successful.

\section{CONCLUSIONS}

For the bronchoscopic removal of an FB, RB is still the approach favored by most clinicians, although a variety of flexible techniques and tools are available. The index case highlights the successful use of a $\mathrm{CO} 2$ cryoprobe for the extraction of a small FB lodged distally in the left lower lobe bronchus that was fully embedded by granulation tissue during a flexible bronchoscopy.

\section{CONFLICTS OF INTEREST}

None declared. 


\section{AUTHOR CONTRIBUTIONS}

Concept - M.A.M.; Planning and Design - M.A.M.; Supervision - M.A.M.; Funding - M.A.M.; Materials M.A.M.; Data Collection and/or Processing - M.A.M.; Analysis and/or Interpretation - M.A.M.; Literature Review - M.A.M.; Writing - M.A.M. Critical Review - M.A.M.

\section{YAZAR KATKILARI}

Fikir - M.A.M.; Tasarım ve Dizayn - M.A.M.; Denetleme M.A.M.; Kaynaklar - M.A.M.; Malzemeler - M.A.M.; Veri Toplama ve/veya İşleme - M.A.M.; Analiz ve/veya Yorum - M.A.M.; Literatür Taraması - M.A.M.; Yazıyı Yazan M.A.M.; Eleştirel İnceleme - M.A.M.

\section{REFERENCES}

1. Moslehi MA. Silence foreign body aspiration syndrome. J Pediatr Neonatal Care 2015; 2(5):00088. [CrossRef]
2. Karakoç F, Karadağ B, Akbenlioğlu C, Ersu R, Yildizeli B, Yüksel $M$, et al. Foreign body aspiration: what is the outcome? Pediatr Pulmonol 2002; 34:30-6. [CrossRef]

3. Kazachkov M, Vicencio A. Foreign body removal is getting "cooler" Pediatr Pulmonol 2016; 51:886-8. [CrossRef]

4. Rodrigues AJ, Scussiatto EA, Jacomelli M, Scordamaglio PR, Gregório MG, Palomino AL, et al. Bronchoscopic techniques for removal of foreign bodies in children's airways. Pediatr Pulmonol 2012; 47:59-62. [CrossRef]

5. Tenenbaum T, Kähler G, Janke C, Schroten H, Demirakca $S$. Management of foreign body removal in children by flexible bronchoscopy. J Bronchology Interv Pulmonol 2017; 24:21-8. [CrossRef]

6. Zhang L, Yin Y, Zhang J, Zhang $H$. Removal of foreign bodies in children's airways using flexible bronchoscopic CO2 cryotherapy. Pediatr Pulmonol 2016; 51:943-9. [CrossRef] 